\title{
KARAKTERISASI VARIETAS UNGGUL BARU (VUB) PADI PADA UJI ADAPTASI DI KABUPATEN MERAUKE MENGGUNAKAN ANALISIS DISKRIMINAN
}

\author{
(Characterisation of New Improved Rice Varieties on Adaptation Test in Merauke Regency \\ Using Discriminant Analysis) \\ Adnan $^{1}$, Fransiskus Palobo ${ }^{2}$ \\ ${ }^{1,2}$ Balai Pengkajian Teknologi Pertanian Papua \\ Jl. Yahim No. 49, Sentani, Jayapura - Papua 99352 \\ Telp (0967) 592179, Fax (0967) 591235 \\ 1e-mail : adnan.msi@pertanian.go.id; aalbahry@yahoo.com
}

Article Submitted : 15-07-2019

Article Accepted : 03-10-2019

\begin{abstract}
The discrimination of new improved rice varieties is important in order to avoid dispute on adaptation test of various new improved varieties at the same time and location. The study aim is to characterize new improved rice varieties on a specific location using discriminant analysis. The data were obtained from the adaptation test database on Aek Sibundong, Inpago 1, Inpari 17, Inpari 18 and Inpari 19 varieties, which was held on January-May 2014 in Merauke Regency. Input parameters for discriminant analysis were the plant high, the number of productive tillers, panicle length, fully filled seed, unfilled seed, and productivity. The results show the first discriminant analysis function represent $86.7 \%$ variance and the fourth function represent $100 \%$ variance. The coefficient of discriminant indicates that productivity gives the biggest contribution to discriminant function. In the end, the accuracy of discriminant analysis to discriminate varieties is $100 \%$.
\end{abstract}

Keywords: new improved varieties; rice; discriminant analysis; Merauke

\section{PENDAHULUAN}

Uji adaptasi varietas unggul baru (VUB) padi dilakukan untuk mengetahui interaksi lingkungan dan genetik. Potensi maksimal hasil hanya bisa diperoleh pada kondisi lingkungan yang cocok. Oleh karena itu, uji multi lokasi diperlukan untuk mengetahui potensi unggul VUB pada kondisi spesifik lokasi (Sitaresmi et al., 2016).

Pada umumnya, pengujian multi lokasi menggunakan beragam VUB berbeda pada waktu dan lokasi yang sama. Pengggunaan beberapa VUB berbeda tersebut bertujuan untuk menentukan VUB yang sesuai pada kondisi agroekosistem pengkajian. Produktitifas biasanya menjadi fokus utama, namun karakteristik lain tetap penting seperti tinggi tanaman untuk menghadapi kondisi lahan dengan kontur miring atau intensitas angin tinggi (Sa'diyah et al., 2014).

Permasalahan terkadang timbul pada proses pasca panen untuk mengidentifikasi VUB karena terdapat beberapa varietas berbeda pada waktu dan lokasi yang sama. Karakteristik VUB yang terkadang serupa serta kemungkinan label tertukar bisa menyebabkan masalah jika tanaman tersebut dijadikan sebagai sumber benih untuk musim tanam berikutnya.

Untuk mengatasi permasalahan tersebut, analisis diskriminan digunakan untuk membedakan antar VUB berdasarkan data karakteristiknya. Data karakteristik berasal dari VUB yang ditanam di Kabupaten Merauke pada bulan Januari sampai Bulan 
Mei 2014 (Palobo and Adnan, 2019). Data karakteristik VUB tersebut ditampilkan pada Tabel Lampiran 1.

Pada penelitian sebelumnya, varietas padi bisa dibedakan berdasarkan perbedaan bentuk dan warna gabah menggunakan analisis diskrimin (Adnan et al., 2015; Landep et al., 2018). Model analisis diskriminan dibangun dari parameter berupa karakteristik atau penciri dari varietas. Parameter input tersebut direduksi oleh model menjadi parameter berbeda dengan dimensi lebih sedikit. Model memperbesar rasio keragaman antar varietas daripada keragaman dalam varietas sehingga menjamin pemisahan antar varietas (Tharwat et al., 2017).

Berdasarkan hal tersebut, penelitian ini bertujuan untuk mengkarakterisasi VUB padi pada uji spesifik lokasi menggunakan analisis diskriminan.

\section{METODE PENELITIAN}

\section{Bahan, Lokasi dan Waktu}

Varietas unggul baru (VUB) padi yang digunakan dalam penelitian ini adalah Aek Sibundong, Inpago 1, Inpari 17, Inpari 18 dan Inpari 19 dengan kelas benih penjenis. Penelitian dilaksanakan di 4 kampung di kabupaten Merauke pada bulan Januari sampai Mei 2014, yaitu kampung Kurik Harapan (Distrik Kurik), kampung Kuper (Distrik Semangga), kampung Sumber Harapan dan Waningaf Miraf (distrik Tanah Miring). Pemilihan lokasi dilakukan secara sengaja untuk mendukung program Kementan dalam mempercepat ketersediaan benih VUB di setiap sentral pengembangan padi di kabupaten Merauke.

\section{Analisis Statistik}

Data hasil uji adaptasi VUB di Merauke (Tabel Lampiran 1) diolah menggunakan aplikasi R versi 3.5.2. Parameter input untuk model analisis diskriminan adalah tinggi tanaman, jumlah anakan produktif, panjang malai, gabah isi, gabah hampa dan produktivitas.

Hasil akhir analisis diskriminan adalah proyeksi matriks data orisinal ke dalalam data berdimensi lebih sedikit. Hasil akhir ini diperoleh dengan melakukan 3 langkah pengolahan data. Tahap pertama adalah menghitung pemisahan antar kelas berbeda, yaitu jarak antar nilai tengah dari kelas berbeda. Teknik ini disebut variasi antar kelas atau matrix antar kelas. Langkah ke dua adalah menghitung jarak antar nilai tengah dan setiap sampel pada masing-masing kelas, disebut sebagai variasi dalam kelas atau matriks dalam kelas. Langkah terakhir adalah membangun model dengan dimensi lebih sedikit yang memaksimalkan variasi antar kelas dan meminimalkan variasi dalam kelas (Tharwat et al., 2017).

\section{HASIL DAN PEMBAHASAN}

Fungsi pertama analisis diskriminan mewakili $86.7 \%$ dari keragaman data (Tabel 1). Fungsi pertama tersebut selalu merupakan yang terbesar dalam mewakili keragaman data. Fungsi selanjutnya mempunyai proporsi yang makin kecil. Akumulasi keragaman data $100 \%$ dicapai pada fungsi ke empat. Fungsi diskriminan yang terbentuk dapat menggantikan keragaman data orisinal menggunakan 6 parameter produksi.

Tabel 1. Proporsi keragaman

\begin{tabular}{ccc}
\hline Faktor & Proporsi(\%) & Akumulasi (\%) \\
\hline LD1 & $86.7 \%$ & $86.7 \%$ \\
LD2 & $11.0 \%$ & $97.7 \%$ \\
LD3 & $2.2 \%$ & $99.9 \%$ \\
LD4 & $0.2 \%$ & $100.0 \%$ \\
\hline
\end{tabular}


Koefisien analisis diskriminan menunjukkan besaran pengaruh parameter terhadap persamaan atau fungsi. Angka koefisien parameter semakin besar menunjukkan parameter tersebut berpengaruh besar sebagai pembeda antar varietas.

Tabel 2. Koefisien analisis diskriminan

\begin{tabular}{lcccc}
\hline Parameter & LD1 & LD2 & LD3 & LD4 \\
\hline Tinggi Tanaman & 0.13469 & -0.07681 & -0.0031 & -0.04733 \\
Jumlah Anakan Produktif & -0.72515 & 0.255613 & -0.26284 & -0.2876 \\
Panjang Malai & -0.33296 & -0.27777 & 0.024938 & -0.1683 \\
Gabah Isi & -0.01954 & -0.04235 & 0.002654 & -0.00704 \\
Gabah Hampa & 0.070136 & -0.00214 & -0.07223 & 0.029797 \\
Produktivitas & -4.80513 & -1.52702 & 0.719957 & 0.282456 \\
\hline
\end{tabular}

Pada Tabel 2, produktivitas pada fungsi pertama (LD1) memiliki koefisien terbesar 4.8 sedangkan parameter lainnya dibawah angka 1.0. Koefisien tersebut menunjukkan bahwa pembeda penting antar varietas pada penelitian ini adalah parameter produktivitas.

Tabel 3. Confusion matrix

\begin{tabular}{clccccc}
\hline & \multicolumn{5}{c}{ Prediksi } \\
\cline { 3 - 6 } & & Aek Sibundong & Inpago1 & Inpari17 & Inpari18 & Inpari19 \\
\hline \multirow{4}{*}{ Aktual } & Aek Sibundong & 4 & 0 & 0 & 0 & 0 \\
& Inpago1 & 0 & 4 & 0 & 0 & 0 \\
& Inpari17 & 0 & 0 & 4 & 0 & 0 \\
& Inpari18 & 0 & 0 & 0 & 4 & 0 \\
& Inpari19 & 0 & 0 & 0 & 0 & 4 \\
\hline
\end{tabular}

Confusion matrix menunjukkan fungsi analisis diskriminan dapat membedakan varietas VUB padi dengan ketepatan 100\%
(Tabel 3). Pembedaan varietas tersebut penting untuk menghindari kemungkinan label tertukar atau pemalsuan benih di lapang.

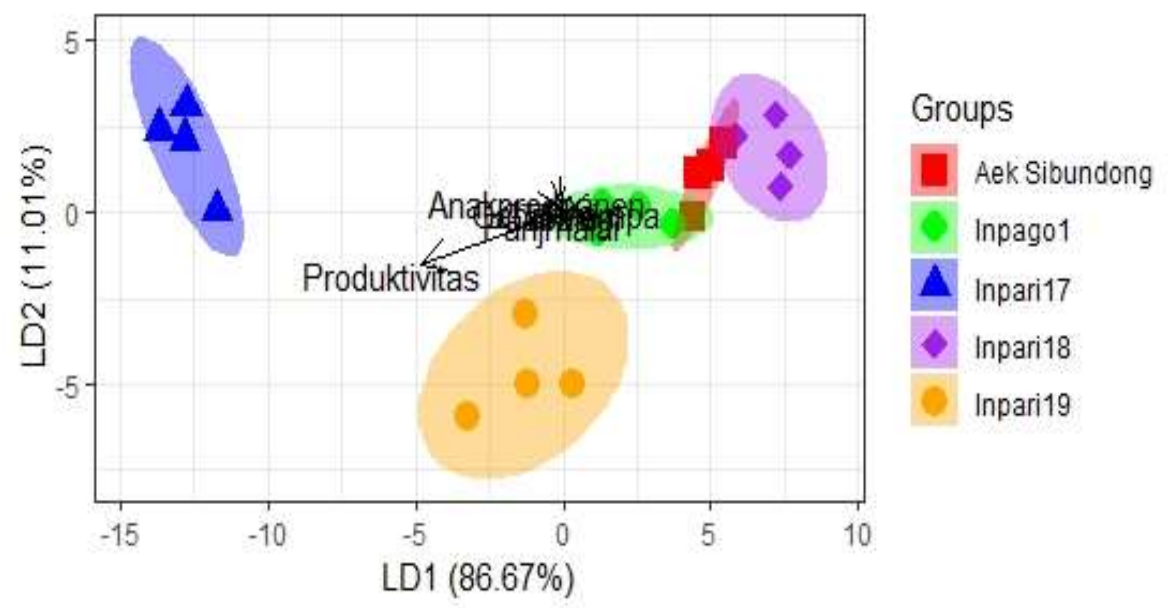

Gambar 1. Bi-plot analisis diskriminan 
Bi-plot pada analisis diskriminan dilakukan untuk mengetahui parameter yang berpengaruh terhadap fungsi diskriminan. Gambar 1 memperlihatkan varietas dapat dibedakan menggunakan analisis diskriminan. Varietas Aek Sibundong dan Inpari 19 mempunyai letak yang cukup berbeda dari varietas lainnya. Pembeda signifikan kedua varietas tersebut dari varietas lainnya adalah produktivitas. Bi-plot mendukung hasil dari koefisien analisis diskriminan yang menunjukkan bahwa produktivitas merupakan parameter penting pembeda varietas. Parameter lain berada di bagian tengah plot, menunjukkan parameter lainnya seperti tinggi tanaman, jumlah anakan produktif, panjang malai, jumlah gabah isi dan jumlah gabah hampa tidak sesuai dijadikan sebagai penciri khas varietas pada penelitian ini.

Pada penelitian lain, analisis diskriminan dapat membedakan 4 jenis padi berbeda yang berasal dari dua lokasi berbeda di Thailand. Parameter masukan untuk model adalah 20 element (Al, $\mathrm{As}, \mathrm{Br}, \mathrm{Ca}, \mathrm{Cd}, \mathrm{Cl}, \mathrm{Co}$, $\mathrm{Cu}, \mathrm{Fe}, \mathrm{Hg}, \mathrm{K}, \mathrm{Mg}, \mathrm{Mn}, \mathrm{Mo}, \mathrm{Na}, \mathrm{P}, \mathrm{Pb}, \mathrm{Rb}$, $\mathrm{S}$, dan $\mathrm{Zn}$ ) yang diperoleh dari laser ablation inductively coupled plasma mass spectrometry. Model diskriminan yang dibangun menghasilkan keakuratan 100\% dan validasi silang menghasilkan keakuratan 97.9\% (Promchan et al., 2016).

\section{KESIMPULAN}

Varietas unggul baru (VUB) padi dikarakterisasi dan diuji menggunakan analisis diskriminan untuk membedakan antar varietas pada lokasi berbeda. Model dibangun dari 6 parameter masukan menghasilkan 4 parameter baru yang mewakili $100 \%$ keragaman. Koefisien diskriminan terbesar terdapat pada parameter produktivitas, menunjukkan bahwa parameter tersebut berkontribusi paling besar terhadap fungsi diskriminan. Analisis diskriminan dapat memprediksi VUB padi dengan keakuratan $100 \%$.

\section{DAFTAR PUSTAKA}

Adnan, Widiastuti, M.L., Wahyuni, S., 2015. Identifikasi Varietas Padi Menggunakan Pengolahan Citra Digital dan Analisis Diskriminan. Penelit. Pertan. Tanam. Pangan 34, 89-96.

Landep, M., Hairmansis, A., Retno, E., Ilyas, S., 2018. Digital image analysis using flatbed scanning system for purity testing of rice seed and confirmation by grow out test. Indones. J. Agric. Sci. 19, 49-56.

Palobo, F., Adnan, 2019. Uji Adaptasi 5 Varietas Unggul Baru Padi Di Kabupaten Merauke. Ziraa'ah 44, 134 141.

Promchan, J., Günther, D., Siripinyanond, A., Shiowatana, J., 2016. Elemental imaging and classifying rice grains by using laser ablation inductively coupled plasma mass spectrometry and linear discriminant analysis. J. Cereal Sci. 71, 198-203. https://doi.org/10.1016/j.jcs.2016.08.01 7

Sa'diyah, H., Sitaresmi, R., Hadi, D.F., 2014. Karakterisasi Galur Harapan Padi Sawah Hasil Penelitian Konsorsium Padi Nasional. Bionatura-Jurnal Ilmuilmu Hayati dan Fis. 16, 142-145.

Sitaresmi, T., Gunarsih, C., Nugraha, Y., Abdullah, B., Hanarida, I., Aswidinnoor, H., Daradjat, A.A., 2016. Interaksi Genotipe x Lingkungan untuk Hasil Gabah Padi Sawah. Penelit. pertan. Tanam. Pangan 35, 89-98.

Tharwat, A., Gaber, T., Ibrahim, A., Hassanien, A.E., 2017. Linear discriminant analysis: A detailed tutorial. AI Commun. 30, 169-190. https://doi.org/10.3233/AIC-170729 
Lampiran 1.

\begin{tabular}{|c|c|c|c|c|c|c|c|}
\hline Varietas & Lokasi & $\begin{array}{l}\text { Tinggi } \\
\text { Tanaman }\end{array}$ & $\begin{array}{c}\text { Jumlah } \\
\text { Anakan } \\
\text { Produktif }\end{array}$ & $\begin{array}{c}\text { Panjang } \\
\text { Malai }\end{array}$ & Gabah Isi & Gabah Hampa & Produktivitas \\
\hline \multirow{4}{*}{ Inpari17 } & Kuper & 79 & 20 & 26.1 & 72.9 & 35.9 & 5.0 \\
\hline & Sumber Harapan & 84 & 27 & 25.0 & 93.5 & 29.0 & 4.2 \\
\hline & Waninggaf Miraf & 51 & 21 & 26.4 & 82.3 & 54.8 & 4.6 \\
\hline & Kurik Harapan & 52 & 22 & 25.8 & 84.0 & 55.2 & 4.4 \\
\hline \multirow{4}{*}{ Inpari18 } & Kuper & 87 & 14 & 23.7 & 63.6 & 39.5 & 2.4 \\
\hline & Sumber Harapan & 89 & 16 & 28.7 & 86.0 & 88.1 & 2.4 \\
\hline & Waninggaf Miraf & 101 & 19 & 23.7 & 82.8 & 50.3 & 2.4 \\
\hline & Kurik Harapan & 110 & 18 & 21.7 & 80.9 & 49.4 & 2.6 \\
\hline \multirow{4}{*}{ Inpari19 } & Kuper & 103 & 16 & 27.8 & 93.4 & 57.0 & 4.2 \\
\hline & Sumber Harapan & 104 & 16 & 30.6 & 132.9 & 57.8 & 3.8 \\
\hline & Waninggaf Miraf & 105 & 16 & 26.4 & 144.3 & 83.6 & 4.2 \\
\hline & Kurik Harapan & 106 & 17 & 27.0 & 149.5 & 79.2 & 4.7 \\
\hline \multirow{4}{*}{$\begin{array}{c}\text { Aek } \\
\text { Sibundong }\end{array}$} & Kuper & 100 & 15 & 25.2 & 90.6 & 31.8 & 2.9 \\
\hline & Sumber Harapan & 100 & 17 & 24.0 & 79.9 & 41.8 & 2.7 \\
\hline & Waninggaf Miraf & 108 & 19 & 23.8 & 68.8 & 38.5 & 2.6 \\
\hline & Kurik Harapan & 105 & 17 & 24.0 & 68.0 & 37.9 & 2.9 \\
\hline \multirow{4}{*}{ Inpago1 } & Kuper & 98 & 14 & 25.1 & 67.6 & 32.4 & 3.7 \\
\hline & Sumber Harapan & 99 & 15 & 24.3 & 78.3 & 25.1 & 3.2 \\
\hline & Waninggaf Miraf & 97 & 13.9 & 25.1 & 85.2 & 31.3 & 3.1 \\
\hline & Kurik Harapan & 98 & 15.3 & 24.9 & 69.2 & 26.8 & 3.4 \\
\hline
\end{tabular}

